\title{
EFEKTIVITAS PENGELOLAAN PEMBELAJARAN MYOB ACCOUNTING BERBASIS WEBLOG DI SMK N 1 SRAGEN
}

\author{
Hindun Khozanah ${ }^{(1)}$, Sutama ${ }^{(2)}$, Djalal Fuadi ${ }^{(3)}$ \\ Universitas Muhammadiyah Surakarta (1) (2) (3)
}

DOI: $10.23917 /$ varidika.v31vi2i.10219

Submission
Track:
Received:
12 August 2019
Final Revision:
12 November 2019
Available online:
27 December 2019
Corresponding
Author:
Name \& E-mail Address
Hindun Khozanah ${ }^{(1)}$, Sutama
, Djalal Fuadi ${ }^{(3)}$
hindunkhozanah56@ gmail.com

\section{Submission}

Track:

12 August 2019

Final Revision:

\begin{abstract}
This study aims to examine the effectiveness of the development of weblog-based MYOB Accounting learning management at SMK N 1 Sragen. This research is an $R \& D$ research. The development model used is Hannafin and Peck Model, with the stages of needs analysis, design, development and implementation. Data collection methods include interviews, questionnaires, observations, and documentation. Then the data were analyzed with descriptive analysis techniques, $t$ test and gain test. The findings in this study are the significance value of the t-count using a weblog of 29.136 and the tcount of the lecture method of 15,581. This conclusions that $t$ count weblog is greater than $t$ count lecture, meaning that the effectiveness of the experimental class using the weblog is better than the control class using the lecture method. The results of the study using the N Gain test also obtained the value of the $N$ Gain percent of the control class was 48.98, while the $N$ Gain percent value of the experimental class was 67.33. The conclusion is learning in the experimental class using weblogs is more effective than the control class using the lecture method. Keywords: learning effectiveness, MYOB Accounting, weblog
\end{abstract}

\section{PENDAHULUAN}


Implementasi pendidikan 4.0 salah satunya dilakukan melalui penerapan kurikulum 2013. Kurikulum 2013 menjelaskan bahwa pada proses pembelajaran, pengetahuan tidak dapat dipindahkan begitu saja dari guru ke peserta didik. Peserta didik adalah subjek yang memiliki kemampuan untuk secara aktif mencari, mengolah, mengkonstruksi dan menggunakan pengetahuan. Oleh karena itu pembelajaran harus memberikan kesempatan kepada peserta didik untuk mengkonstruksi pengetahuan dalam proses kognitifnya. Dengan demikian, konsep pembelajaran bergeser dari pembelajaran berpusat pada guru (teacher centered) menjadi pembelajaran berpusat pada siswa (student centered) (Permendikbud No. 70 Tahun 2013).

Pada proses pembelajaran sesuai kurikulum 2013, guru memiliki peranan yang sangat penting yaitu sebagai fasilitator dalam pembelajaran. Oleh karena itu guru harus memiliki kompetensi dalam penguasaan teknologi informasi dan komunikasi (TIK). Teknologi informasi dan komunikasi memiliki peranan dalam pembelajaran untuk membantu tercapainya efektivitas dan efisiensi tujuan pembelajaran serta meningkatkan mutu pembelajaran.

Pembelajaran menggunakan teknologi informasi yang dapat diterapkan pada pendidikan salah satunya adalah menggunakan weblog. Weblog merupakan salah satu produk yang dihasilkan oleh internet dan dapat dimanfaatkan sebagai sumber belajar. Beberapa manfaat weblog pada pembelajaran adalah mudah diakses, materi yang disajikan tidak hanya berupa teks tetapi juga disertai gambar dan video sehingga tidak membosankan, dapat langsung mem-posting materi, dan dapat mengatasi keterbatasan ruang, waktu dan daya indra (Hikmawan dan Syaichudin, 2011). Pemanfaatan weblog sebagai bahan ajar menjawab tuntutan dari kurikulum 2013 tentang perubahan pola pembelajaran. Pemanfaatan weblog juga diharapkan memberikan pembaharuan dalam proses pembelajaran di kelas maupun di rumah yang dapat digunakan sebagai proses belajar mandiri (self directed learning) siswa.

Penelitian yang dilakukan oleh Said Fathy El Said Abdul Fattah (2016) dalam "The Effectiveness of Using Blogs as an Independent Learning Tool to Develop Reading Skills for University Students" menyatakan bahwa weblog dapat digunakan sebagai alat untuk mengefektifkan belajar mandiri dalam membangun kemampuan membaca peserta didik pada siswa Sekolah Lanjutan Tingakat Pertama. Hasil t-test mengungkapkan bahwa menggunakan blog menghasilkan efek yang signifikan pada keterampilan membaca siswa, yaitu kelompok eksperimen mengungguli kelompok kontrol.

Yu-Chun Kuo, Brian R. Belland and Yu-Tung Kuo (2017) tentang Learning through Blogging: Students' Perspectives in Collaborative BlogEnhanced Learning Communities menuliskan bahwa pembelajaran blog secara signifikan berkontribusi terhadap rasa memiliki komunitas dari peserta didik. Peserta didik menunjukkan sikap yang positif terhadap penggunaan blog dan pengalaman belajar kelompok yang melibatkan proses kolaboratif pada pengembangan pengetahuan dan keterampilan. Dalam pembelajaran kolaboratif, pengalaman pembelajaran bersama memungkinkan peserta terlibat dalam diskusi, berkomunikasi dengan peserta didik lain dan menyajikan ide-ide (Kuo, Walker, Belland \& Schroder, 2013).

Berbagai masalah dalam proses pembelajaran $M Y O B$ Accounting di kelas dialami oleh guru ketika menyampaikan materi di SMK Negeri 1 Sragen. Diantara penyebabnya adalah kompleksitas mata pelajaran $M Y O B$ Accounting yang tinggi dibandingkan dengan produktif akuntansi yang lain karena menggunakan istilah-istilah asing dalam programnya dan harus dioperasikan secara berurutan agar entri transaksi benar dan laporan keuangan valid. Alokasi waktu untuk mempelajari MYOB Accounting hanya 5 jam pelajaran dalam satu minggu, dan alokasi waktu ini masih terpotong dengan adanya siswa praktek kerja lapangan selama tiga (3) 
bulan di dunia industri. Alokasi jam ini dirasa sangat kurang untuk mengoptimalkan pembelajaran karena kerumitan cara mengoperasikan program MYOB Accounting dan banyaknya materi yang harus disampaikan ke siswa.

Fakta di lapangan yang terjadi di SMK Negeri 1 Sragen, proses pembelajaran $M Y O B$ Accounting masih menggunakan metode ceramah dibantu media power point. Hal ini membuat siswa bosan karena konten dalam media power point terbatas pada poin-poin pokok bahasan. Akibat lain dari metode konvensional ini adalah kurangnya interaksi guru dan siswa dalam pembelajaran, rendahnya kemandirian belajar siswa, rendahnya komunikasi dan kolaborasi siswa, siswa merasa jenuh dan berdampak pada rendahnya pencapaian hasil belajar siswa yaitu sebesar 56,11 (dibawah kriteria ketuntasan minimal).

Berdasarkan teori dan permasalahan di atas, secara umum peneliti bertujuan pengembangan pengelolaan pembelajaran $M Y O B$ Accounting berbasis weblog di SMK N 1 Sragen. Seca khusus tujuan penelitian ini untuk menguji efektivitas pengembangan pengelolaan pembelajaran $M Y O B$ Accounting berbasis weblog.

\section{METODE PENELITIAN}

Penelitian ini adalah penelitian Research and Development ( $\mathrm{R} \& \mathrm{D})$. Model penelitian pengembangan yang digunakan adalah model Hannafin and Peck, dengan tahapananalisis kebutuan, perancangan, pengembangan dan implementasi. 1) Tahap analisis kebutuhan, dilakukan identifikasi kebutuhan dengan menggali informasi terhadap media pembelajaran, 2) tahap perancangan, dilakukan perancangan/desain produk media pembelajaran weblog dilengkapi dengan penjelasan untuk mempermudah dalam memahami media yang dirancang, 3) pengembangan \& implementasi, pada tahap ini disiapkan draft media pembelajaran weblog yang akan dikembangkan berupa teks, gambar, foto, video dan sebagainya, kemudian diberi penjelasan dengan bahasa yang komunikatif kemudian dilakukan dengan pengujian, 4) evaluasi dan revisi, pada tahap ini dilakukan evaluasi dan revisi terhadap media pembelajaran yang dihasilkan, serta adanya saran perbaikan dari para ahli media dan materi.Selanjutnya dilanjutkan uji coba dan uji lapangan.

Data dikumpulkan dari ahli media, ahli materi, dokumen sekolah, hasil belajar peserta didik serta tanggapan guru dan peserta didik. Teknik pengumpulan data meliputi wawancara, angket, observasi, dan dokumentasi. Selanjutnya data dianalisis dengan teknik analisis deskriptif, uji t dan uji gain. Tahapan model pengembangan Hannafin and Peckyang digunakan pada penelitian ini ditunjukkan seperti gambar 1 dibawah ini :

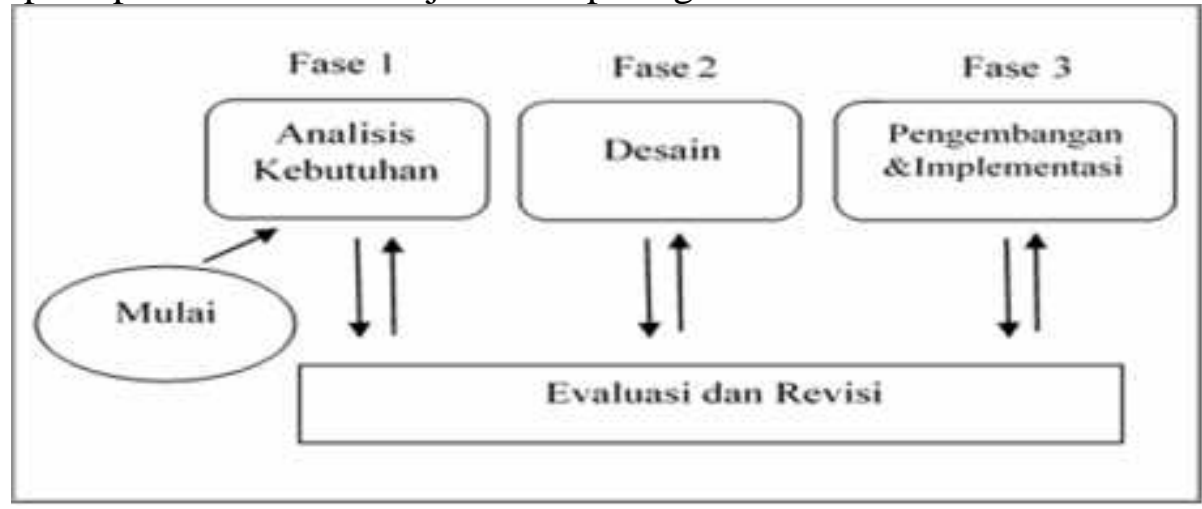

Gambar 1. Model pengembangan Hannafin and Peck

\section{HASIL PENELITIAN}

Efektivitas pengembangan pembelajaran $M Y O B$ Accounting berbasis weblog di SMK Negeri 1 Sragen diperoleh dari hasil belajar kelas eksperimen dengan menggunakan weblog 
dan kelas kontrol dilakukan dengan pembelajaran konvensional melalui uji t dan uji gain. Hasil uji t dari kelompok eksperimen adalah nilai t hitung adalah 29,136 sedangkan t tabel $t$ tabel sebesar 2,03. Artinya $\mathrm{t}$ hitung $>\mathrm{t}$ tabel, yang mengandung makna ada perbedaan ratarata antara hasil belajar pre test dengan post test yang artinya ada perbedaan hasil belajar peserta didik setelah menggunakan weblog dalam pembelajaran diterima dengan signifikan. Secara rinci hasil uji t dari kelas eksperimen dapat dilihat pada tabel 1.

Tabel 1 Tabel Hasil T-Test Kelas Eksperimen

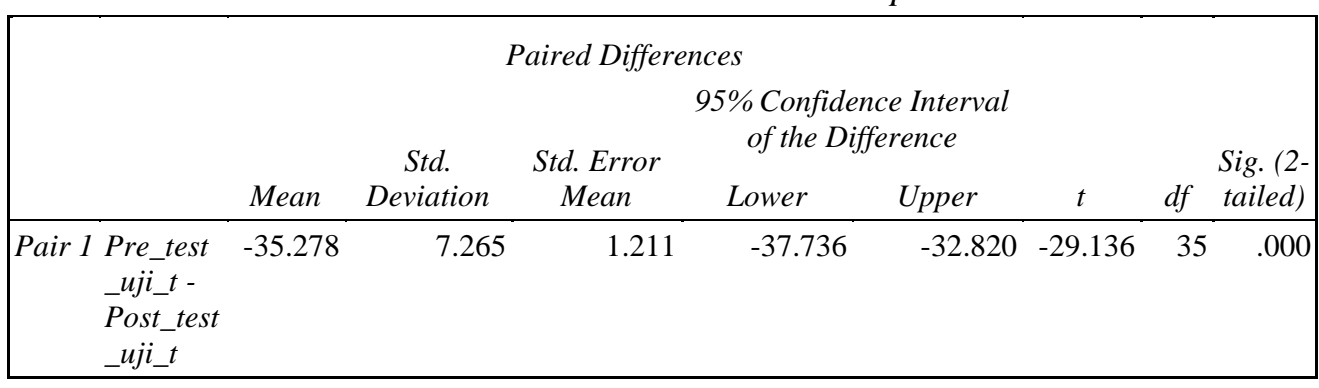

Sedangkan hasil uji t kelas kontrol adalah nilai t hitung adalah 23,917 sedangkan t tabel sebesar 2,03. Artinya $t$ hitung $>\mathrm{t}$ tabel yang mengandung makna ada perbedaan rata-rata antara hasil belajar pre test dengan post test . Hal ini berarti ada perbedaan hasil belajar peserta didik setelah menggunakan metode ceramah dalam pembelajaran.

Tabel 2 Tabel Hasil T-Test Kelas Kontrol

\begin{tabular}{|c|c|c|c|c|c|c|c|c|c|}
\hline & & & & red Difference & & & & & \\
\hline & & & & Std. Error & $\begin{array}{r}95 \% \text { Confi } \\
\text { Interval } \\
\text { Differe }\end{array}$ & $\begin{array}{l}\text { lence } \\
\text { the } \\
\text { ce }\end{array}$ & & & \\
\hline & & Mean & Deviation & Mean & Lower & Upper & $t$ & $d f$ & tailed) \\
\hline Pair 1 & $\begin{array}{l}\text { Pre_tes_kon- } \\
\text { Pos_tes_Kon }\end{array}$ & -27.500 & 10.590 & 1.765 & -31.083 & -23.917 & -15.581 & 35 & .000 \\
\hline
\end{tabular}

Berdasarkan hasil t-test kedua kelas antara kelas kontrol dan kelas eksperimen diperoleh nilai t-hitung menggunakan weblog sebesar 29,136 dan t-hitung metode ceramah sebesart 15,581. Hal ini mengandung makna bahwa t hitung weblog lebih besar dari thitung ceramah, artinya efektifitas kelas eksperimen yang menggunakan weblog lebih baik daripada kelas kontrol yang menggunakan metode ceramah.

Uji peningkatan (gain) dilakukan untuk mengetahui peningkatan hasil belajar kelompok eksperimen yang mendapat pembelajaran menggunakan weblog pada materi pengelolaan kartu piutang, utang dan persediaan dak kelompok kontrol yang dilakukan melalui pembelajaran konvensional. Adapun Hasil uji gain diperoleh nilai N Gain persen dari kelas kontrol adalah 48,98, sedangkan nilai $\mathrm{N}$ Gain persen dari kelas eksperimen adalah 67,33. Secara rinci uji N Gain dapat dilihat pada tabel 3di bawah ini :

Tabel 3. Hasil Uji N-Gain

\begin{tabular}{|ccccc|}
\hline Kelompok & $\begin{array}{c}\text { Rata-Rata } \mathrm{N} \\
\text { Gain Percen }\end{array}$ & Minimal & Maximal & Kriteria \\
\hline Kelas Kontrol & 48.98 & 11,11 & 72,73 & Tidak Efektif \\
Kelas Eksperimen & 67,33 & 40,00 & 87,50 & Efektif \\
\hline
\end{tabular}

\section{PEMBAHASAN}


Temuan terhadap pengelolaan pembelajaran $M Y O B$ Accounting berbasis Weblog di SMK N 1 Sragen menggunakan uji t menunjukkan bahwa hasil siginifikansi t-test kedua kelas antara kelas kontrol dan kelas eksperimen diperoleh nilai siginifikansi t-hitung menggunakan weblog sebesar 29,136 dan signifikansi t-hitung metode ceramah sebesar 15,581. Hal ini mengandung makna bahwa $\mathrm{t}$ hitung weblog lebih besar dari $\mathrm{t}$ hitung ceramah, artinya efektifitas kelas eksperimen yang menggunakan weblog lebih baik daripada kelas kontrol yang menggunakan metode ceramah.

Hasil penelitian menggunakan uji N Gain juga diperoleh nilai uji N Gain persen dari kelas kontrol adalah 48,98, sedangkan nilai $\mathrm{N}$ Gain persen dari kelas eksperimen adalah 67,33. Kesimpulannyaadalah pembelajaran untuk kelas kontrol termasuk kategori kurang efektif, sedangkan pembelajaran untuk kelas eksperimen termasuk kategori efektif. Berdasarkan keseluruhan hasil uji diperoleh temuan bahwa pengelolaan pembelajaran $M Y O B$ Accounting berbasis weblog di SMK N 1 Sragen efektif.Berbagai uji statistik yang dilakukan didukung dengan respon peserta didik pada kegiatan pembelajaran. Respon peserta didik kelas XI AKL 1 sebagai kelas eksperimen terhadap pembelajaran MYOB Acconting berbasis weblog adalah baik dengan rata-rata persentase $79 \%$, dan respon guru adalah sangat baik dengan persentase $87 \%$.

Hasil penelitian ini selaras dengan hasil penelitian yang telah dilakukan sebelumnya oleh Sri Sartono, M. Harlanu dan Agus Suryanto (2012) tentang Efektivitas Pemanfaatan Free Weblog Sebagai Classroom Blogging menyatakan bahwa penggunaan weblog mampu meningkatkan kemampuan belajar mahasiswa Teknik Elektro Universitas Negeri Semarang pada mata kuliah sitem multimedia, juga meningkatkan kemampuan berfikir kreatif mahasiswa. Penelitian yang dilakukan oleh Yayu Laila Sulastri dkk (2016) tentang pembelajaran kalkulus I menggunakan weblog menyatakan bahwa terdapat pengaruh pembelajaran menggunakan weblog terhadap hasil belajar mahasiswa. Pembelajaran menggunakan weblog terbukti efektif untuk pembelajaran terhadap mahasiswa dengan berbagai karakteristik.

Yu-Chun Kuo, Brian R. Belland and Yu-Tung Kuo (2017) tentang Learning through Blogging: Students' Perspectives in Collaborative Blog Enhanced Learning Communities menuliskan bahwa pembelajaran blog secara signifikan berkontribusi terhadap rasa memiliki komunitas dari peserta didik. Peserta didik menunjukkan sikap yang positif terhadap penggunaan blog dan pengalaman belajar kelompok yang melibatkan proses kolaboratif pada pengembangan pengetahuan dan keterampilan. Dalam pembelajaran kolaboratif, pengalaman pembelajaran bersama memungkinkan peserta terlibat dalam diskusi, berkomunikasi dengan peserta didik lain dan menyajikan ide-ide (Kuo, Walker, Belland \& Schroder, 2013).

Penelitian-penelitian tersebut memberi gambaran bahwa weblog dapat membantu siswa untuk melakukan pembelajaran mandiri (self directed learning) dan membatu peserta didik dalam memahami materi pembelajaran. Hipotesis pada penelitian ini yang berbunyi weblog efektif dalam pengembangan pengelolaan pembelajaran MYOB Accounting di SMK Negeri 1 Sragen diterima. Weblog terbukti efektif dan layak digunakan untuk pembelajaran $M Y O B$ Accounting di SMK N 1 Sragen pada materi pengelolaan kartu piutang, utang dan persediaan.

\section{SIMPULAN}

Kondisi awal pembelajaran $M Y O B$ Accounting di SMK N 1 Sragen dibutuhkan sebuah media pembelajaran yang dapat digunakan untuk mempermudah kegiatan pembelajaran, media yang sesuai tuntutan kurikulum 2013, dan mampu mengefektifkan hasil belajar. Selanjutnya dilakukan pengembangan pengelolaan pembelajaran MYOB Accounting berbasis 
weblog yang menggunakan model pengembangan Hannafin and Peck. Model pengembangan pembelajaran $M Y O B$ Accounting Berbasis Weblog dinyatakan layak oleh ahli media dan ahli materi. Tahap terakhir adalah melalui uji $\mathrm{t}$ dan uji gain diperoleh simpulan bahwa pengembangan pembelajaran $M Y O B$ Accounting Berbasis weblog di SMK Negeri 1 Sragen terbukti efektif meningkatkan hasil belajar peserta didik.

\section{DAFTAR PUSTAKA}

Cristina Oddone. 2012. Blog, Videoblog Eaudioblog Nelladidattica Dellelingue. Tdtecnologie Didattiche, 20 (2), pp. 123-126

Hartono. 2012. Efektivitas Weblog Dan Facebook Terintegrasi Untuk Pembelajaran Virtual. Jurnal Cakrawala Pendidikan. Februari 2014. No. 1

Hikmawan, RA dan Syaichudin, M. 2011. Pengembangan Blog Pembelajaran untuk Meningkatkan Hasil Belajar Siswa Pada mata Pelajaran Geografi Materi keragaman Bentuk Muka Bumi kelas VII di SMP Gema 45 Surabaya. Tesis. Surabaya : Unesa.

Kuo YC, Walker A, Belland B. R \& Schroder K. E. E . 2013. A Predictive Study Of Student Satisfaction In Online Education Programs. The International Review Of Research In Open And Distance Learning, 14 (1), 16-39. Doi:10.19173/irrodl.v14i.1338

Said Fathy El Said Abdul Fattah. 2016. The Effectiveness of Using Blogs as an Independent Learning Tool to Develop Reading Skills for University Students. Journal of Education and Practice. ISSN 2222-1735 (Paper) ISSN 2222-288X (Online). Vol.7, No.32, 2016.

Sri Sartono, M. Harlanu, Agus Suryanto. 2012. Efektivitas Pemanfaatan Free Weblog Sebagai Classroom Blogging Berbasis Web di Jurusan Teknik Elektro Untuk Meningkatkan Hasil Belajar Mahasiswa. Jurnal Penelitian Pendidikan Vol. 29 Nomor 2 Tahun 2012. Hal 155-164

Sugiyono. 2016. Metode Penelitian Kuantitatif, Kualitatif dan R\& D. Bandung : Alfabeta

Sutama. 2019. Metode Penelitian Pendidikan Kuantitatif, Kualitatif, PTK, Mix Method, $R$ \& D. Kartasuro : Jasmine

Yayu Laila Sulastri, A. Barnas EK, Luki Luqmanul Hakim. 2016. Pembelajaran Kalkulus I Dengan Menggunakan Weblog Pada Mahasiswa Pendidikan Matemaatika FKIP UNINUS Bandung. Jurnal Pengajaran MIPA Vol 19 No. 1. Hal 40-46

Yu-Chun Kuo, Brian R. Belland and Yu-Tung Kuo. 2017. Learning through Blogging: Students Perspectives in Collaborative BlogEnhanced Learning Communities. Educational Technology \& Society, 20 (2), 37-50 